\title{
Managing Complicated Diabetic Foot Ulcers with Peripheral Arterial Disease
}

\author{
Sung Hoon Yu (D), Dong Chul Kim (D), Chi Ho Shin (D) \\ Department of Plastic and Reconstructive Surgery, Bundang Jesaeng Hospital, Seongnam, Korea
}

\begin{abstract}
Background: Diabetic foot ulcers are an issue of clinical interest as diabetes has become the leading cause of occlusive vasculopathy. The purpose of this study is to evaluate the clinical outcomes and the effect of revascularization in diabetic foot ulcers with peripheral arterial occlusive disease (PAOD).

Methods: A total of 46 patients who had surgical treatment for diabetic foot ulcers were evaluated. We conducted an intergroup comparison of their baseline demographic and clinical characteristics, and also compared surgical outcomes between cases with and without PAOD, and also between cases on which revascularization had and had not been performed.

Results: Major amputation was performed on 10 patients (21.7\%). Minor amputation and reconstructive surgery were performed on 24 patients (52.2\%) and 12 patients (26.1\%), respectively. In the 19 patients (41.3\%) with severe obstruction, eight patients (42.1\%) underwent major amputation. In the patients without severe obstruction, two patients (7.4\%) underwent major amputation. The high proportion of major amputation in patients with severe obstruction was statistically significant $(\mathrm{P}<0.01)$. Among the 19 patients with severe obstruction, nine (47.4\%) underwent revascularization and 10 patients (52.6\%) did not. In the patients who had revascularization, one patient $(11.1 \%)$ had major amputation. In the patients who did not have revascularization, seven $(70.0 \%)$ underwent major amputation. The low proportion of major amputation in patients undergoing revascularization was statistically significant $(P=0.02)$.

Conclusion: Results of this study demonstrate that preoperative evaluation of peripheral arterial disease and revascularization are important for reducing the risk of major amputation.
\end{abstract}

Keywords: Foot ulcer, diabetic; Peripheral arterial disease; Computed tomography angiography; Angioplasty; Major amputation

\section{서 론}

당뇨병은 만성 대사성 질환으로 매년 증가하고 있다. 2018년 한국에서 실시한 국민건강영양조 사에 따르면, 나이를 보정한 당뇨 환자의 비율이 2007년 9.5\%에서 2018년 10.4\%로 $0.9 \%$ 증가(남 자는 $11.8 \%$ 에서 $12.9 \%$ 로 $1.1 \% \mathrm{p}$ 증가, 여자는 7.2\%에서 $7.9 \%$ 로 $0.7 \% \mathrm{p}$ 증가)하였다[1]. 그리고 이러 한 당뇨 환자의 약 $5 \%-10 \%$ 가 평생 한 번 이상 당뇨병성 족부 병변을 경험하며, 당뇨병성 족부 궤양이 비외상성 하지 절단의 $50 \%$ 이상을 차지한다고 알려져 있다[2,3]. 한 연구에 의하면, 절 단 이후 $50 \%$ 의 환자에서 5 년 이내에 사망하거나 반대편 하지에 대한 절단 수술이 시행되었다 고 한다[4]. 당뇨병성 족부 궤양의 발생 기전으로는 혈관 변화에 따른 혈류 장애, 말초 신경병증 에 의한 감각의 이상, 감염에 대한 저항력의 저하 등이 복합적으로 작용하는 것으로 보고되고 있다[3,5]. 말초혈관 질환은 당뇨병성 족부 궤양의 원인이자 치유 지연의 원인이 될 수 있으며 절 단의 가장 중요한 위험 인자로 보고되고 있다[6]. 따라서 당뇨병성 족부 궤양 환자의 치료에 있 어 말초 혈류 상태를 확인하고 필요한 경우 혈류를 개선하는 시술이 중요하다고 할 수 있는데, 경피경관 혈관성형술(percutaneous transluminal angioplasty, PTA)은 궤양 치료에 있어 중요한 조직 허혈 상태 개선에 도움이 되며, 시행 4 주 후 허혈성 조직 산소공급이 최대수준에 이르는 것으로 알려져 있다[7].

그동안 국내에서 말초동맥질환 동반 여부에 따른 당뇨병성 족부 궤양의 치료결과에 대한 연

\section{Original Article}

Received: May 23, 2020

Revised: September 3, 2020

Accepted: September 5, 2020

\section{Corresponding author: \\ Dong Chul Kim, M.D., Ph.D.}

Department of Plastic and Reconstructive Surgery, Bundang Jesaeng Hospital, 20 Seohyeon-ro 180beon-gil, Bundang-gu, Seongnam 13590, Korea

Tel: +82-31-779-0281

Fax: +82-31-779-5032

E-mail: nevus@naver.com

This is an Open Access article distributed under the terms of the Creative Commons Attribution Non-Commercial License (https://creativecommons.org/licenses/by-nc/4.0/) which permits unrestricted non-commercial use, distribution, and reproduction in any medium, provided the original work is properly cited.

(c) 2020 Korean Wound Management Society 
구는 많지 않았으며 수술적 처치가 필요한 당뇨병성 족부 궤양 환자 들의 혈관재관류술(revascularization) 시행 여부와 치료결과에 대한 연구는 거의 없었다. 이에 저자들은 수술적 처치가 필요한 당뇨병성 족부 궤양 환자들의 말초동맥질환 동반 유무 및 혈관재관류술 시행 여부와 치료결과와의 상관관계에 대해 조사하였으며, 치료결과를 통 해 수술 전 말초동맥질환 검사 및 혈관재관류술 시행의 중요성에 대 해알아보고자 연구를 시행하였다.

\section{방 법}

\section{연구 대상}

2015년 6월부터 2020년 2월까지 약물치료나 배농술 등의 보존적 치 료가 어려워 수술을 시행한 당뇨병성 족부 궤양 환자 46 명을 대상으 로 후향적 연구를 시행하였다. 이 중 발목 관절부위 위에서 절단술(대 절단)을 시행한 10 명을 Group I로 분류하였으며, 대절단술을 시행하 지 않은 36명을 Group II로 분류하였는데, Group II는 발목 관절부위 보다 아래에서 절단술(소절단)을 시행한 24명과 연부조직 재건술(피 부이식술, 국소피판술)을 시행한 12 명이 포함된 군이다. 재발하여 여 러 번 절단술을 받은 환자는 최종 절단술을 기준으로 분류하였다.

\section{연구 방법}

각 그룹에 대해 나이, 성별, 흡연력, 동반질환, 당화혈색소( $\mathrm{HbAlc})$, 당 뇨병 이환 기간 등을 조사하였디. 수술 전 시행한 하지 혈관조영단층 검사(lower extremity CT angiography)에서 동측 말초동맥의 중증도 협착(severe obstruction) 동반 여부와 이에 따른 혈관재관류술 시행 여부를 조사하여, 동측 말초동맥에 1 개 이상의 직경 $75 \%$ 이상 협착병 변이 있는 경우 중증도 협착이 동반된 환자군으로 정의하였다. 혈관
재관류술을 시행 받은 환자는 경피경관 혈관성형술 또는 대퇴동맥슬와동맥 우회술(femoral popliteal bypass)을 시행 받은 환자들로 정 의하였다(Fig. 1).

저자들은 수술이 필요한 당뇨병성 족부 궤양 환자들에게 대절단 술 보다는 재건술 혹은 소절단술을 위해 입원 시 상완-발목 지수(ankle brachial index, ABI), 상완-발목 맥파속도(brachial-ankle pulse wave velocity), 하지 혈관조영단층검사를 이용하여 말초동맥질환 동 반 여부를 검사하였는데, $\mathrm{ABI}$ 값이 0.9 이상이더라도 상완-발목 맥파 속도 검사 값이 동일나이 평균보다 2 표준편차 이상 벗어나 있는 경우 에는 확진을 위해 하지 혈관조영단층검사를 시행하였다. 이러한 검 사들을 통하여 혈관 막힘 여부를 정확히 판단하고, 막힌 혈관 위치에 따라 혈관재관류술(PTA 또는 femoral popliteal bypass)을 타과 협의 진료를 통해 시행하였다. 족부 X-선 촬영과삼상골 스캔(3-phase bone scan) 검사를 시행하여 변연절제술의 범위를 결정하였는데, 재건 수 술이 필요한 경우 수술 전 감염된 뼈를 포함한 괴사조직 변연절제술 을 시행하였다. 족부 X-선과 삼상골 스캔 검사상 감염이 1 개 관절 이 상을 침범한 경우 근위부에서 절단술 또는 이단술을 시행하였으며, 관절을 침범하지 않은 경우 감염된 뼈를 포함한 괴사조직 제거 후 국 소 피판술 혹은 피부이식술을 시행하였다(Fig. 2).

\section{분석 방법}

통계적 분석은 SPSS version 26.0 (IBM Corp., Armonk, NY, USA)을 활용하여 명목척도 간의 통계적 유의성 검증을 하고자 독립 표본 T 검정(independent samples t-test), 카이제곱검정(chi-square test), 및 비 모수검정(Fisher exact test)을 실시하였다. 통계학적 유의 수준은 P값 이 0.05 미만인 경우로 하였다.

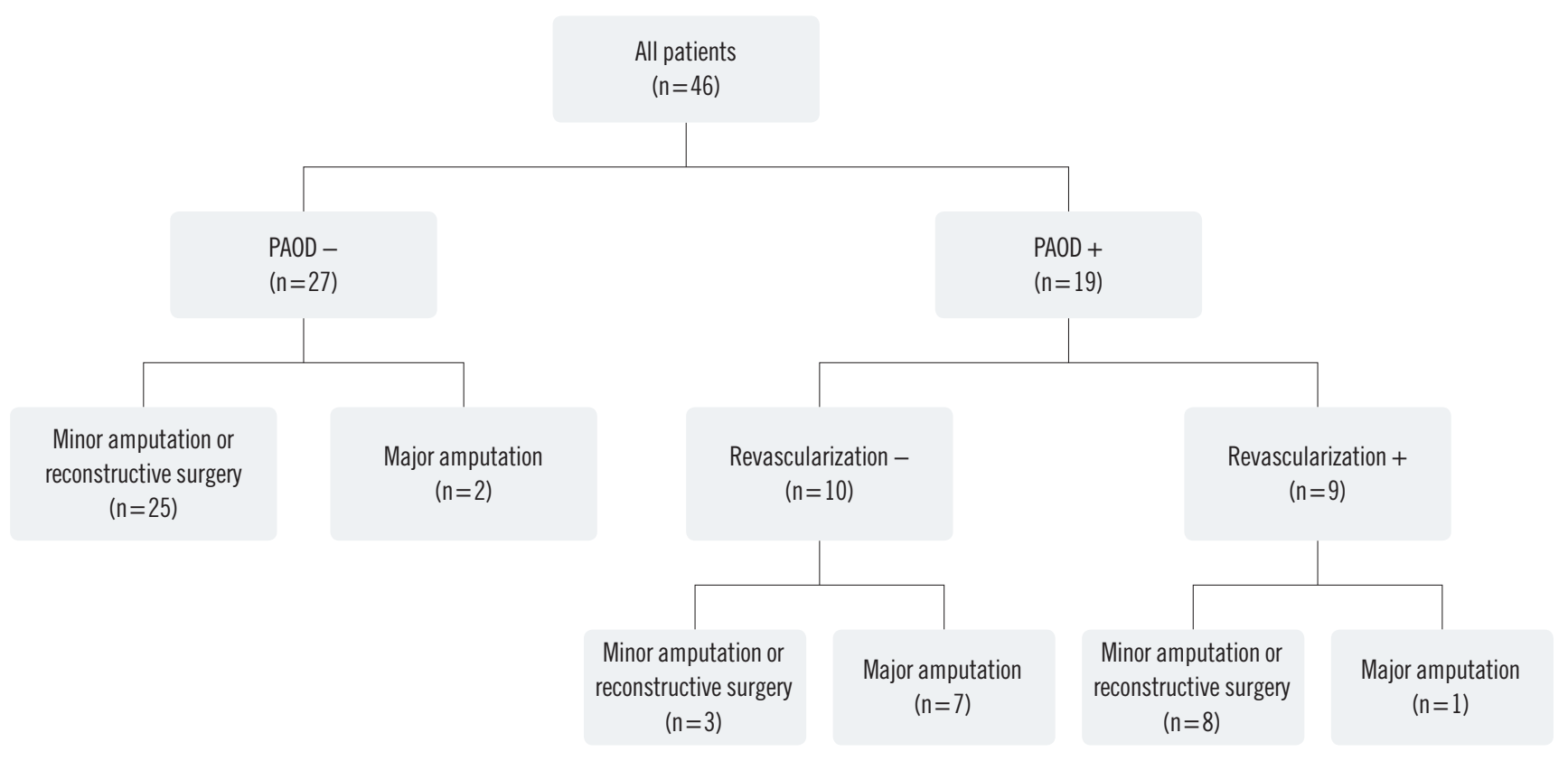

Fig. 1. Flowchart of patients. PAOD, peripheral arterial occlusive disease. 


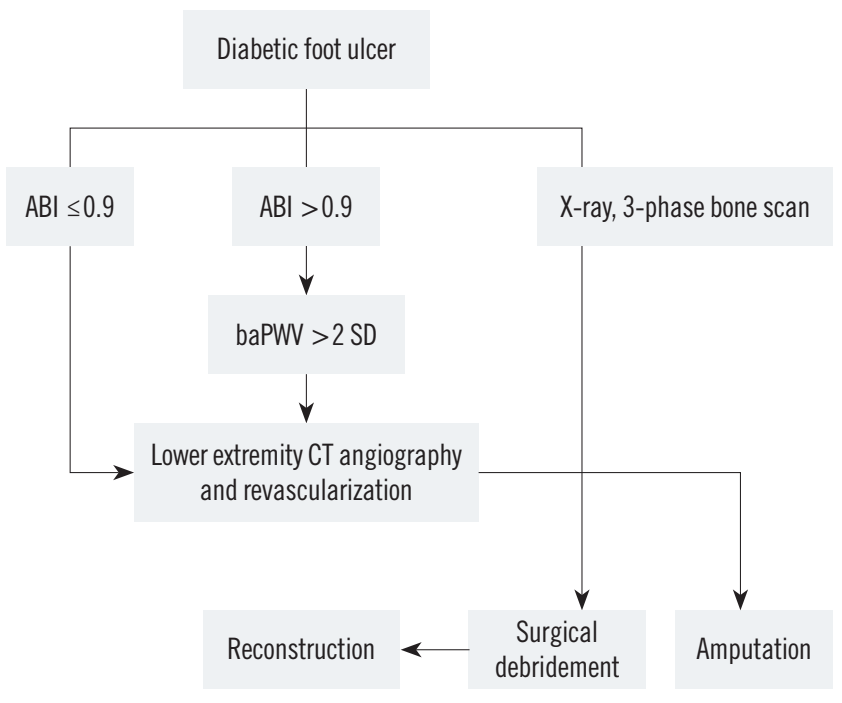

Fig. 2. Clinical course of diabetic foot ulcer with peripheral arterial occlusive disease. $\mathrm{ABI}$, ankle brachial index; baPWV, brachial-ankle pulse wave velocity; SD, standard deviation; CT, computed tomography.

\section{결 과}

당뇨병성 족부 궤양 환자 46 명 중에서 대절단술을 시행 받은 환자는 10 명(21.7\%), 소절단술은 24 명(52.2\%), 재건술은 12 명(26.1\%)이었으며, 대절단술을 시행 받은 Group I에서는 평균 연령이 $68.90 \pm 11.22$ 세, 대 절단술을 시행 받지 않은 Group II에서는 $65.33 \pm 13.47$ 세였다. Group I 은 남자가 9명, 여자가 1명, Group II에서 남자가 20명, 여자가 16명이었 으며, Group I과 Group II 모두에서 나이, 성별, 흡연력, 동반 질환, 당 뇨 이환 기간, 당화혈색소 수치에 따른 통계적으로 유의한 차이는 없 었다(Table 1).

하지 동맥에 중증도 협착이 동반된 말초동맥질환 환자는 총 19 명 (41.3\%)이었으며, 19 명을 조사한 결과 궤양 발생 시점부터 말초동맥질 환 진단 검사를 받기까지 걸린 기간은 평균 $1.9 \pm 2.6$ 개월이었다. 동측 하지동맥에 중증도 협착이 동반된 말초동맥질환 환자 중, Group I은 8 명(42.1\%), Group II는 11명(57.9\%)이었고, 중증도 협착이 없는 환자 중, Group I은 2명(7.4\%), Group II는 25명(92.6\%)으로, 중증도 협착이 동반된 경우 통계적으로 유의하게 $(\mathrm{P}<0.01)$ 대절단의 비율이 높았으 며, 결과적으로 대절단술을 시행 받은 환자의 $80 \%$ 에서 동측 하지동 맥의 중증도 협착이 동반되어 있었다(Fig. 3).

중증도 협착이 동반된 말초동맥질환 환자 19 명 중 혈관재관류술 을 시행한 환자는 9 명(47.4\%)이었으며, 시술 실패 2 명을 포함하여 전신 상태 불안정, 환자거부 등으로 혈관재관류술을 시행 받지 못한 환자 는 10명(52.6\%)이었다. 혈관재관류술을 시행한 경우 대절단(Group I) 1 명(11.1\%), 소절단 혹은 재건술(Group II) 8명(88.9\%), 혈관재관류술을 시행 받지 않은 경우 대절단 7명(70.0\%), 소절단 혹은 재건술 3 명 (30.0\%)으로, 혈관재관류술을 시행 받은 환자군의 경우 통계적으로 유의하게 $(\mathrm{P}=0.02)$ 대절단의 비율이 낮았다(Fig. 4$)$.
Table 1. Demographics and clinical characteristics of patients $(n=46)$

\begin{tabular}{lccc}
\hline Factors & $\begin{array}{c}\text { Group I } \\
(\mathrm{n}=10)\end{array}$ & $\begin{array}{c}\text { Group II } \\
(\mathrm{n}=36)\end{array}$ & P-value \\
\hline Age (yr) & $68.90 \pm 11.22$ & $65.33 \pm 13.47$ & 0.45 \\
Sex & $9(90.0)$ & $20(55.6)$ & 0.07 \\
Male & $1(10.0)$ & $16(44.4)$ & \\
Female & $5(50.0)$ & $12(33.3)$ & 0.46 \\
Smoking & & & \\
Comorbidity & $8(80.0)$ & $21(58.3)$ & 0.28 \\
Hypertension & $2(20.0)$ & $6(16.7)$ & 1.00 \\
Ischemic heart disease & $2(20.0)$ & $8(22.2)$ & 1.00 \\
Cerebrovascular accident & $5(50.0)$ & $8(22.2)$ & 0.12 \\
Chronic kidney disease & $2(20.0)$ & $7(19.4)$ & 1.00 \\
Diabetic retinopathy & $3(30.0)$ & $2(5.6)$ & 0.06 \\
Cancer & & & \\
DM & $14.10 \pm 10.64$ & $14.11 \pm 10.17$ & 1.00 \\
Duration (yr) & $8.22 \pm 2.92$ & $8.92 \pm 2.59$ & 0.46 \\
HbAlc (\%) & & & \\
\hline
\end{tabular}

Values are presented as mean \pm SD or number (\%). Group I is the major amputation group and group II is the non-major amputation group (minor amputation + reconstruction).

DM, diabetes mellitus; HbAlc, glycated hemoglobin.

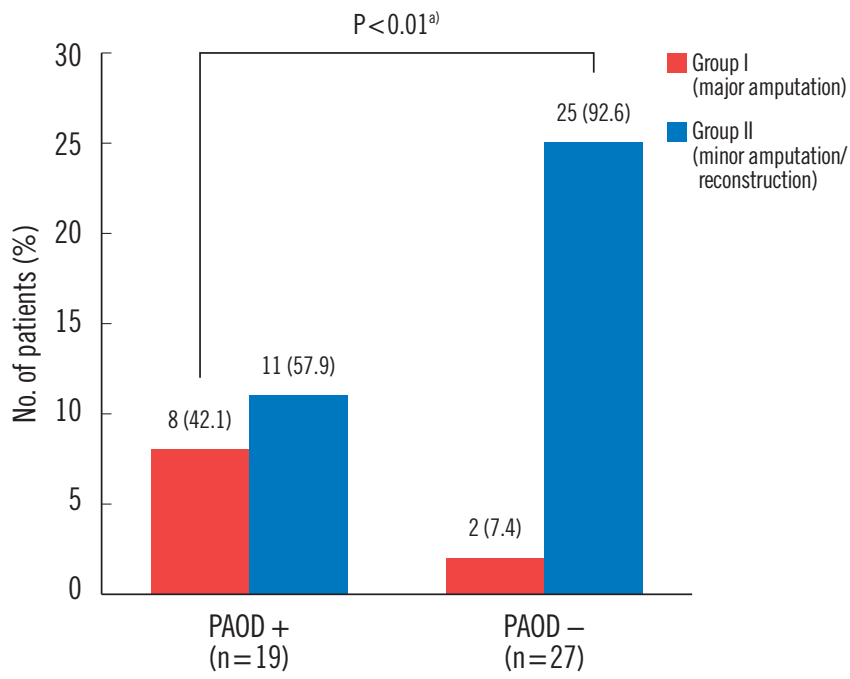

Fig. 3. Comparison between two groups. PAOD, peripheral arterial occlusive disease. ${ }^{\text {a) }}$ Statistically significant difference.

\section{사례 1}

77 세 여자 환자로 17 년 전부터 당뇨병을 않아 왔으며 오른쪽 안쪽 복 사(medial malleolus) 부위의 외상으로 한 달간 말초동맥질환 검사 없 이 1차 병원에서 고식적 드레싱 및 항생제 치료를 받았으나 호전 없이 궤양이 악화되어 외래를 통해 입원하였다. 혈액 검사상 당화혈색소는 


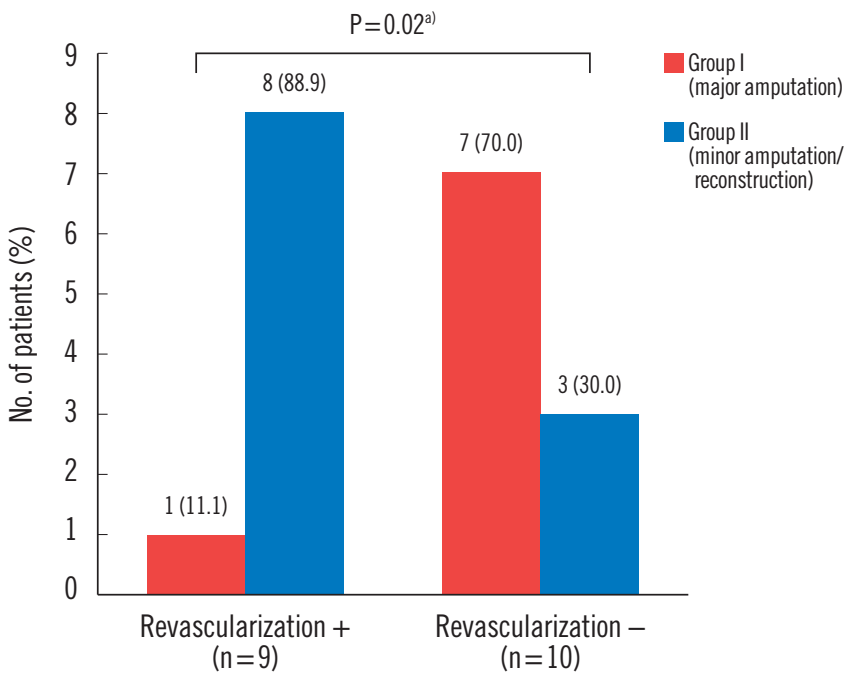

Fig. 4. Comparison between two groups. ${ }^{\text {a) }}$ Statistically significant difference.

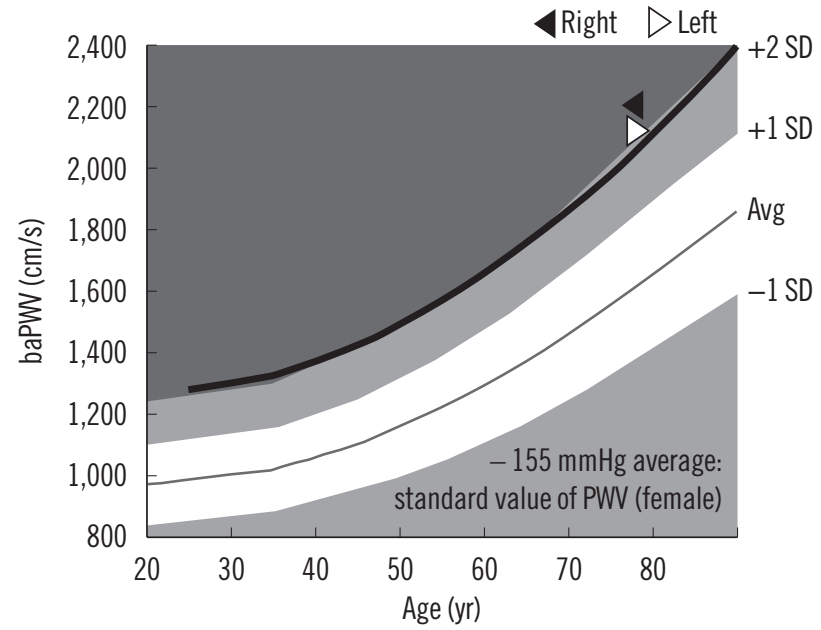

Fig. 5. The value of the right foot's baPWV (black arrowhead). baPWV, brachial-ankle pulse wave velocity.

$7.2 \%$, 궤양은 $3 \times 3 \mathrm{~cm}$ 크기의 연부조직 괴사와 함께 감염소견이 있는 상태였다. 검사상 $\mathrm{ABI}$ 는 1.13 으로 정상이었으나 함께 측정한 상완-발 목 맥파속도 검사값이 동일나이 평균보다 2 표준편차 이상 벗어나 있 어(Fig. 5), 하지 혈관조영단층검사를 시행하였다. 검사상 전경골동맥 (anterior tibial artery)과 비골동맥(peroneal artery)이 각각 근위부에서 중증도 협착 소견이 있었다. 폐색된 동맥의 재개통을 위해 혈관재관 류술(PTA)을 시행하였으며, 이후 환부에 육아조직이 빠르게 성장하 였고, 가장자리의 상피화가 진전되었다. 혈관재관류술 2 주 뒷부분층 피부 이식술을 하였고, 이식된 피부는 수혜부에 잘 생착하였으며 입 원 34일째 퇴원하였다(Fig. 6).

\section{사례 2}

80 세 여자 환자로 20 년 전부터 당뇨병을 않아 왔으며 오른쪽 발가락
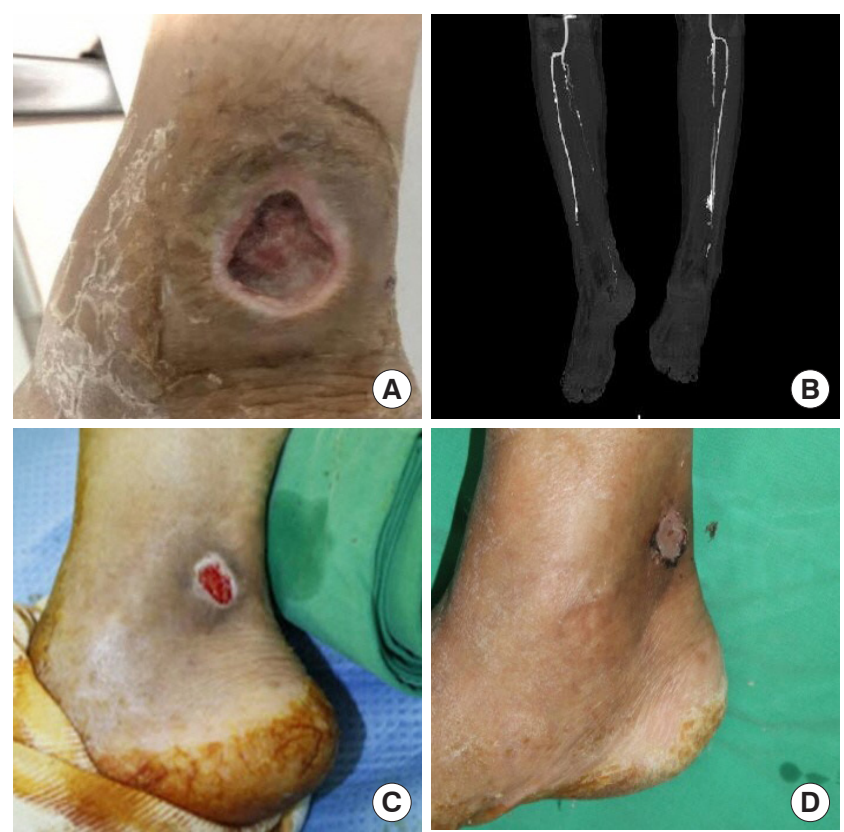

Fig. 6. Clinical images of case 1. (A) Clinical photograph showing chronic ulcer on right medial malleolus. (B) Lower extremity computed tomogrphy angiography showing severe stenosis at both proximal anterior tibial artery and proximal peroneal artery. (C) Two weeks after angioplasty, relatively healthy granulation tissue was observed. (D) On postoperative day 14, the graft took well.
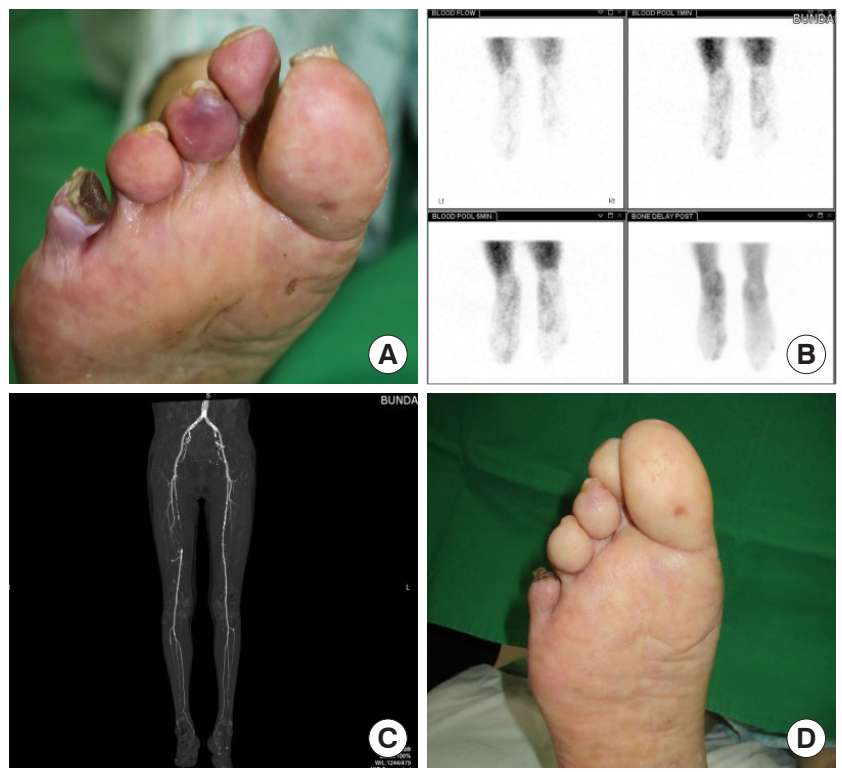

Fig. 7. Clinical images of case 2. (A) Clinical photograph showing skin necrosis on the right 5 th toe and ischemic rubor on the 2 nd and 3rd toes. (B) Three-phase bone scan showing osteomyelitis on the right 5th toe's distal phalanx. (C) Lower extremity computed tomography angiography showing severe stenosis at superficial femoral artery. (D) Clinical photograph at post-bypass graft after 19 days, showing disappearance of ischemic rubor and improved peripheral circulation. 

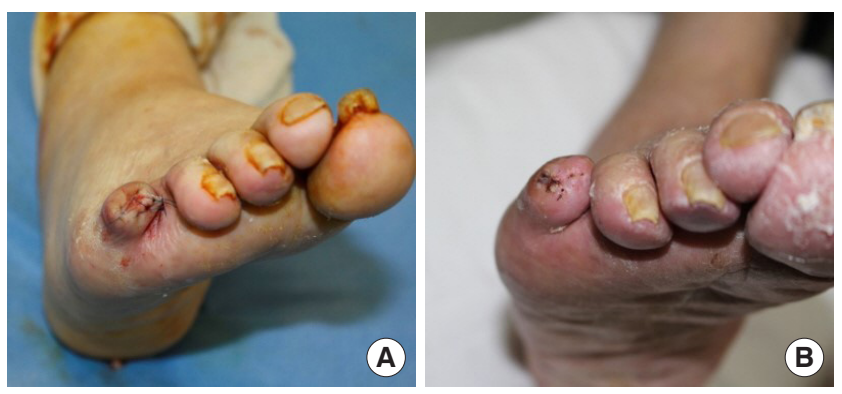

Fig. 8. Clinical images of case 2. (A) Immediate postoperative. (B) Clinical photograph at post-amputation on the 25th day when the wound was successfully closed.

의 피부 궤양 및 괴사로 3 개월간 말초동맥질환 검사 없이 1 차 병원에 서 고식적 드레싱 치료받았으나 호전 없이 괴사 진행되어 외래를 통 해 입원하였다. 혈액 검사상 당화혈색소는 $6.3 \%$, 다섯번째 발가락의 괴사 진행이 관찰되었으며, 나머지 발가락에는 허혈성 홍조(ischemic rubor)가 관찰되었다. 검사상 $\mathrm{ABI}$ 는 0.76 , 하지 혈관조영단층검사상 표재대퇴동맥(superficial femoral artery)에 중증도 협착 소견이 있었 으며, 삼상골 스캔 검사상 골수염은 끝마디뼈에만 국한되어 있는 소 견이었다(Fig. 7). 이에 따라 골수염과 괴사가 진행된 다섯 번째 발가 락 말단부와주변 연부조직의 변연절제술을 시행함과 동시에 혈관재 관류술(femoral popliteal bypass)을 시행하였다. 혈관재관류술 약 2 주 뒤 발가락 허혈성 홍조는 호전된 양상을 보였고, 다섯 번째 발가락에 만 끝마디뼈 절단술을 시행하였으며, 수술 25 일 후 특이 합병증 없이 퇴원하였다(Fig. 8).

\section{고 찰}

미국 당뇨학회에 의하면 당뇨 환자에서의 절단술은 매년 80,000 건 이상 시행되고 있고, 당뇨가 전체 절단 원인의 $60 \%$ 이상이라고 한다 [8]. 절단은 발가락 절단과 같은 소절단, 발목 관절 상부에서 시행하는 대절단 등이 있으며, 대절단의 경우 그 합병증이 심각할 수 있겠다. 연 구에 의하면 대절단 후 5 년 이내에 반대쪽 다리를 절단할 가능성이 약 50\% 이상이며, 절단 후 5년 생존율이 약 $40 \%$ 정도라 한다 $[9,10]$. 당 뇨병성 족부 궤양은 치료가 어려우며, 재발률이 높아 절제술의 경우 에도 수술 범위 결정이 어려운데, 재수술에 대한 부담 때문에 처음부 터 대절단 수술을 원하는 환자도 있으나, 보행장애 및 합병증을 고려 하여 가능한 소절단술 및 재건술을 시행하는 것이 치료의 궁극적 목 표라 할 수 있다. 최근 소절단 수술 후 재수술률이 $10 \%$ 정도로 낮게 보고되고 있고, 족부의 혈액 공급이 좋지 않아 광범위 절제가 필요한 경우라도 혈관재관류술 시행으로 말초 혈액 공급을 향상시켜 상처 치료의 성공률을 높이거나 원위부에서 성공적으로 절단술을 시행 할 수도 있어 가능하면 소절단을 일차적으로 고려하는 비율이 높아 지고 있는 추세이다[11,12]. 최근 연구에 따르면 당뇨병성 족부 궤양 주변부에 시행하는 지방유래간질혈관분획세포 피하 주사가 허혈성 당뇨족의 미세순환 개선에 효과적이라는 연구 결과가 잇따르는 등,
허혈성 당뇨족의 말초 혈액 순환 개선을 위한 여러 노력들이 계속되 고 있다[13]. 본 연구 결과에서도 말초혈관질환이 있는 환자의 경우 대 절단술의 비율이 높아지나 혈관재관류술을 시행 받은 경우 대절단 술의 비율이 낮아지는 것을 확인할 수 있었다. 또한 6 개월 이상 혈관 재관류술이 지연된 환자 2 명은 모두 대절단 수술을 받아야 했는데, 말초동맥질환은 증상이 없는 경우가 많고, 증상이 있더라도 전형적 인 증상보다는 비전형적인 증상이 많기 때문에 위험인자가 있는 환 자를 대상으로 보다 적극적인 선별검사, 정확한 진단과 적절한 치료 가 필요하다. 연구에 따르면, 당뇨병성 족부 궤양이 있는 환자에서 말 초동맥질환의 유병률은 보고에 따라 $10 \%-60 \%$ 에 이른다고 한다 $[14,15]$. 이러한 말초동맥질환의 선별검사로 $\mathrm{ABI}$ 가 대표적이며, 미국 당뇨병학회에서는 50 세 이상의 당뇨병 환자에게 $\mathrm{ABI}$ 를 측정하고 정 상이면 5년마다 반복 측정하도록 하며, 50세 미만이라 하더라도 흡 연, 고혈압, 고지혈증이 있는 경우, 당뇨병 이환 기간이 10 년 이상인 경 우, 말초동맥질환 증상이 있는 경우라면 선별검사를 하도록 권고하 고 있다[16]. ABI는 비침습적이며 간단하고, 비용이 저렴한 측정 방법 으로 비교적 간단한 장비만 있으면 일차 진료실에서 쉽고 간편하게 시행할 수 있다. 하지만 연구들에 따르면, 동맥경화가 심하거나 당뇨 환자의 경우 선별검사로써 $\mathrm{ABI}$ 검사는 특이도가 높지만 민감도는 낮 다는 결과들이 많으며, 이러한 경우 도플러 초음파나 발가락상완지 수(toe-brachial index) 등의 선별검사를 추가로 실시하여 보완할 수 있다[17]. 앞서 본 연구 결과에서 보듯 19명(41.3\%)의 중증도 협착이 동 반된 말초동맥질환 환자들 중 궤양 발생 시점부터 처음 말초동맥질 환 진단을 위한 검사를 받기까지 걸린 기간은 평균 $1.9 \pm 2.6$ 개월이었 는데, 입원 즉시 검사를 시행했음에도 말초동맥질환 진단을 위한 검 사가 늦어진 이유를 조사한 결과, 우선 말초동맥질환 선별검사인 $\mathrm{ABI}$ 검사를 하지 않은 채로 1 차 의료기관에서 궤양 자체에 대한 치료 만 받으며 검사시기가 늦어진 이유가 가장 많았고, 환자의 과소평가, 타과에서의 진단 지연 등이 있었다. 이러한 결과는 당뇨병성 족부 궤 양 환자들에게 동반되어 있을 가능성이 있는 말초동맥질환에 대한 검사의 중요성에 대해 1 차 의료기관 및 타과 의료진과의 정보 교류, 이 에 대한 환자 교육 등이 필요함을 시사하며 향후 혈관재관류술 시행 시점 차이에 따른 재건 수술 및 절단술 결과의 비교 연구가 필요할 것 으로 사료된다.

본 연구에서의 제한점은 후향적 연구를 시행하였다는 점과, 혈관 재관류술 시행여부에 따른 두 집단 간의 비교에 있어 환자의 시술 의 지, 환자의 전신상태 등의 바이어스(bias)가 존재할 수 있다는 점이 있 으며, 당뇨병성 족부 궤양 환자 분석에 있어서 오랜 기간 동안 추적연 구를 시행하지 못했다는 점을 지적할 수 있겠다.

본 연구에서 총 46 명의 수술을 시행한 당뇨병성 족부 궤양 환자들 을 분석한 결과 대절단술을 시행 받은 환자는 $21.7 \%$, 소절단술 $52.2 \%$, 재건술 $26.1 \%$ 로 나타났다. 대절단술을 시행 받은 환자의 $80 \%$ 에서 동 측 하지동맥의 중증도 협착이 동반되어 있었으며, 혈관재관류술을 시행 받은 9명 중 1명(11.1\%) 만이 대절단술을 시행 받아 그 비율이 낮 음을 확인할수 있었다. 이는 당뇨병성 족부 궤양 환자에 있어 수술 전 말초동맥질환 검사를 하고, 하지동맥의 협착 정도에 따라 혈관재관 
류술을 시행하여 보행장애나 합병증의 위험이 높은 대절단술의 비 율을 낮추는 데 도움이 된다는 것을 보여주는 중요한 연구 결과라 사 료된다.

\section{이해 관계}

이논문에는 이해 관계 충돌의 여지가 없음

\section{ORCID iDs}

Sung Hoon Yu https://orcid.org/0000-0002-9524-5224

Dong Chul Kim https://orcid.org/0000-0003-3244-7918

Chi Ho Shin https://orcid.org/0000-0002-7418-1575

\section{References}

1. Korea Centers for Disease Control and Prevention. 2018 Korea National Health and Nutrition Examination Survey [Internet]. Cheongju: Korea Centers for Disease Control and Prevention; c2020 [cited 2020 Oct 13]. Available from: https://knhanes.cdc.go.kr/knhanes/main.do.

2. Boulton AJ, Vileikyte L, Ragnarson-Tennvall G, et al. The global burden of diabetic foot disease. Lancet 2005;366: 1719-24.

3. Waugh NR. Amputations in diabetic patients: a review of rates, relative risks and resource use. Community Med 1988; 10:279-88.

4. Dargis V, Pantelejeva O, Jonushaite A, et al. Benefits of a multidisciplinary approach in the management of recurrent diabetic foot ulceration in Lithuania: a prospective study. Diabetes Care 1999;22:1428-31.

5. Most RS, Sinnock P. The epidemiology of lower extremity amputations in diabetic individuals. Diabetes Care 1983;6: 87-91.

6. Reiber GE, Raugi GJ. Preventing foot ulcers and amputations in diabetes. Lancet 2005;366:1676-7.

7. Kim HR, Han SK, Rha SW, et al. Effect of percutaneous transluminal angioplasty on tissue oxygenation in ischemic diabetic feet. Wound Repair Regen 2011;19:19-24.

8. Philbin TM, Berlet GC, Lee TH. Lower-extremity amputations in association with diabetes mellitus. Foot Ankle Clin 2006;11:791-804.

9. Resnick HE, Carter EA, Lindsay R, et al. Relation of lowerextremity amputation to all-cause and cardiovascular disease mortality in American Indians: the Strong Heart Study. Diabetes Care 2004;27:1286-93.

10. Tentolouris N, Al-Sabbagh S, Walker MG, et al. Mortality in diabetic and nondiabetic patients after amputations performed from 1990 to 1995: a 5-year follow-up study. Diabetes Care 2004;27:1598-604.

11. Bae JI, Won JH, Han SH, et al. Endovascular revascularization for patients with critical limb ischemia: impact on wound healing and long term clinical results in 189 limbs. Korean J Radiol 2013;14:430-8.

12. Canaud L, Alric P, Berthet JP, et al. Infrainguinal cutting balloon angioplasty in de novo arterial lesions. J Vasc Surg 2008;48:1182-8.

13. Moon KC, Chung HY, Han SK, et al. Possibility of injecting adipose-derived stromal vascular fraction cells to accelerate microcirculation in ischemic diabetic feet: a pilot study. Int J Stem Cells 2019;12:107-13.

14. Armstrong DG, Lavery LA, Harkless LB. Validation of a diabetic wound classification system: the contribution of depth, infection, and ischemia to risk of amputation. Diabetes Care 1998;21:855-9.

15. Oyibo SO, Jude EB, Tarawneh I, et al. The effects of ulcer size and site, patient's age, sex and type and duration of diabetes on the outcome of diabetic foot ulcers. Diabet Med 2001;18:133-8.

16. American Diabetes Association. Peripheral arterial disease in people with diabetes. Diabetes Care 2003;26:3333-41.

17. Aboyans V, Criqui MH, Abraham P, et al. Measurement and interpretation of the ankle-brachial index: a scientific statement from the American Heart Association. Circulation 2012;126:2890-909. 